\title{
The Telephonic Work of Spanish Pioneer Electrician Enrique Bonnet
}

\author{
Jesús Sánchez Miñana* and Carlos Sánchez Ruiz**. \\ *Universidad Politécnica de Madrid, Madrid, and Centre de Recerca per a la Història de la Tècnica, \\ Universitat Politècnica de Catalunya, Barcelona. **Ateneo Literario, Artístico y Científico de Cádiz, Cádiz, \\ Spain.
}

\begin{abstract}
The authors summarize the results of their research to bring to light and put into an international context the activities of this little-known, Cádiz-based inventor and entrepreneur who seems to have built Bell-type telephones as early as 1876, introducing his own commercial version in January 1878. In June 1878 he also had Hughes-type microphones for sale, and one year later he had combined them with his telephones in a set that included all the necessary elements to make and receive calls. Details of these instruments are given, taken from the descriptions written by Bonnet himself in an 1882 patent, and by one of his superiors in the State Telegraphs in a book published in 1884. Some considerations on the diffusion of his apparatus are also included.
\end{abstract}

Index Terms — Telephony, history.

\section{INTRODUCTION}

The important role played by Enrique Bonnet Ballester (Murcia, 1837 - Cádiz, 1905) in the introduction of the applications of electricity in Spain was recently pointed out by one of the authors in a short biographical work [1]. For many years a State telegrapher assigned to the Cádiz office, Bonnet also initially ran a watchmaking business in the city that provided him with the means to turn his knowledge and inventiveness into prototypes and operational devices. Concerning telegraphy he built, among other things, a fast double-polarity, Morse-type system that worked successfully in the Spanish network and received an honorary mention at the Universal Exhibition of 1867 and a silver medal at the International Electrical Exhibition of 1881, both held in Paris, as well as an ABC apparatus for private communications that he put on sale as early as 1868, and a night optical telegraph (1874) intended for use by Government troops in the fight against the Carlist rebels. His long-time interest in electric light led him, after a visit to the 1881 Exhibition, to undertake for several years the occasional illumination of public spaces in Cádiz and other neighbouring towns, using rotary generators and different kinds of lamps, one of which was the incandescent type that he introduced in 1883. With this experience, he was granted a concession by the City Council of Seville in 1890 to supply electricity to the town, a business that he transferred to another operator in 1902.
Bonnet was also very involved in telephony. What follows is a brief account of the authors' findings so far about his activities in this field, with a view to framing them within the Spanish and international developments concerning the new invention. This task has been hindered by the lack of direct sources of information, since according to his contemporaries Bonnet was a man of great modesty with little inclination to writing for the public. Furthermore, no personal records, should he have kept them, or letters have been found.

\section{EARLY EXPERIMENTS}

According to the testimony of a fellow telegrapher named Alfonso Márquez Rodríguez, Bonnet began experimenting with Alexander Graham Bell's telephone very early. In a biographical outline of his colleague published in a 1889 journal, Márquez wrote the following:

"In 1876, when news arriving to us from North America about the invention of the telephone was both scant and sketchy $^{1}$, Señor Bonnet built two of these apparatus, perhaps the first ones to be tried in Spain and probably the first to be built in our country. Those who had the pleasure of witnessing those first tests, when the telephone still had the charm that surrounds all that is new and unknown, will always remember the emotion that we felt when hearing the human word coming across an immense distance by means of those crude wooden ear-trumpets" ${ }^{2}$.

Unfortunately no other sources confirming these words have been found. However, the rest of the story having been proved scrupulously correct in all its details, there seems to be little reason to question this particular point, considering moreover that the writer includes himself among those attending the experiments. Eighteen-year old Márquez, who lived with his family at San Fernando, a town very close to Cádiz, must have stayed in Madrid at least from October 1, 1876, when he started taking examinations to become a State telegrapher, until March 2, 1877, on which date, after having passed the exams, he obtained his commission. On the 19th of the same

\footnotetext{
${ }^{1}$ In the Spanish original: "En 1876, y cuando apenas nos llegaban noticias inciertas de la América del Norte sobre la invención del teléfono...”

2 “D. Enrique Bonnet y Ballester”, El Telegrafista Español, Madrid, June 19, 1889, pp. 117-120.
} 
month, he is known to have reported for work at the Cádiz Telegraph station, where Bonnet had been serving since $1866^{3}$. Thus, if the telephone trials really did take place in 1876, they must have been conducted earlier than October.

The news of Bell's speaking telephone had reached Europe by that time, and in spite of its scarcity and lack of detail, may nevertheless have been sufficient to strike the attention of electricians whose minds were open to innovative ideas, as Bonnet's certainly was, and inspire them to make their own experiments. On June 1, 1876, the Telegraphic Journal, a leading London electrical publication to which Telégrafos, the Spanish Telegraphs, probably subscribed, copied some paragraphs from the Daily Expositor of Brantford (Ontario, Canada) reporting that Bell had just obtained in Washington a patent "for a new method of telegraphy, by mean of an undulatory instead of an intermittent current"4. The magazine underlined the words "undulatory" and "intermittent", thereby pointing out the key to the invention. The description of the apparatus that followed was less fortunate though not incorrect:

“... from an electro-magnet at one end of a single wire are heard issuing the sounds of the human voice -tones and words which were spoken or sung before a membrane connected with an electro-magnet at the other end of the wire”.

An article entitled "Experiments in telephony", which appeared on the front page of the August 11 issue of another major technical review of broader coverage, The English Mechanic and World of Science and Art, was much more precise. It was allegedly based on a report of Bell's demonstration at the Massachusetts Institute of Technology in May of the same year:

"Two single-pole electro-magnets, each having a resistance of 10 ohms, were arranged in circuit with a battery of five carbon elements -the total resistance being about 25 ohms. A drumhead of goldbeater's skin, about 23/4 in. in diameter, was placed in front of each electro-magnet, and a circular piece of clock-spring was glued to the middle of the membrane of each drumhead. One of these telephones was placed in the experimental room, and the other in the basement of an adjoining house”.

Returning to Marquez's testimony, either a lapse in memory or just a typographical error in the year of Bonnet's demonstrations cannot be completely discarded, so that these experiments might have actually taken place in 1877, and in that case not earlier than March, considering the young telegraphic candidate's schedule in Madrid. The fact that Márquez and Bonnet were already working together can be

\footnotetext{
${ }^{3}$ Personal records of Márquez and Bonnet in the Archivo de Correos $y$ Telégrafos, Madrid.

${ }^{4}$ His famous U. S. patent 174,465, filed February 14, 1876 and granted March 7.
}

invoked in favour of this hypothesis, while no indication has been found of a previous relation between them.

Europe learned again about Bell's telephone via the brief, though accurate, description given by Sir William Thomson on September 7, 1876 at the Glasgow meeting of the British Association for the Advancement of Science, transcribed in full by the London Times the following day and by Nature on the 14th. In his address, Thomson showed the apparatus that Bell had given him in Boston, and on October 1 The Telegraphic Journal gave more details of them. Images would not appear until December 22, when another British magazine, Engineering, published drawings of both the transmitter and receiver. Bonnet might have had access to this information. Moreover, he could have read an acceptable version of Thomson's words that appeared on October 5 on El Imparcial of Madrid, one of the main Spanish newspapers of the day ${ }^{5}$.

It is well known that Bell and his assistant, machinist Thomas A. Watson, continued working on the improvement of the telephones that Thomson had been made aware of, and that, especially during 1877 until some weeks before the inventor's journey to Britain in July, they carried out a campaign of public demonstrations in the United States. However, the technical details of their achievements were rather late to arrive in Europe, and this time apparently the publication was the Scientific American. The reports that this magazine published on February 24 and March 31 (illustrated in the latter issue with drawings taken from Bell's last patent ${ }^{6}$ ), inspired La Nature of Paris, of March 17 and April 21.

In Spain, the Revista de Telégrafos, official monthly publication of the State organization, dealt with the telephone for the first time in its issue of April 1, 1877, in an article that gave a rather unclear description of the device ${ }^{7}$. On June 1 the magazine provided a better one ${ }^{8}$, illustrated with the above mentioned drawings from Engineering, wile on August 1 it included a translation from La Nature of April 21. All this may well have motivated Bonnet's experiments, should he not have done them before.

The first commercial telephones arrived in Great Britain as part of Bell's luggage. Together with them and some other units that Gardiner G. Hubbard, his father-in-law and trustee of the newly established Bell Telephone Company, subsequently sent to a trader in Paris ${ }^{9}$, the days of scant and sketchy news of the invention were certainly coming to an end.

\footnotetext{
${ }^{5}$ It was taken from an unknown issue of the Journal Officiel de la République Française. As far as the authors have been able to check, the great daily Parisian press, a regular source of news for their Spanish counterpart, did not report on Thomson's reference to the telephone.

${ }^{6}$ U. S. patent 186,787, filed January 15, 1877 and granted on the 30th.

${ }^{7}$ Translated from L'Elettricista of Florence, likely of February 1877.

${ }^{8}$ Translated from La Nature, April 7, 1877.

${ }^{9}$ His name was Charles Le Gay. See Hubbard's letter to his son-in-law dated November 2, 1877, available on the internet from the Library of Congress, Washington, D. C.
} 


\section{TELEPHONES}

After the experiment witnessed by Márquez, Bonnet's work on the telephone must have undoubtedly continued, but nothing is known about it until February 1, 1878, when the newspaper Diario de Cádiz reported a new demonstration conducted the day before to a small group of people at the Gran Teatro in the city. Placed some eighty meters apart on different storeys of the theatre, they perfectly exchanged speech and songs. "Glory to the inventor of the telephone!", one of them said, prompting the answer from the anonymous reporter "And to its builder in Cádiz!”. This gentleman did not bother to describe for his readers the telephones that were used, although he made it clear that they were no longer test specimens but finished commercial units, since they could be made to operate "from house to house and even from town to town", and Bonnet "without paying any tribute abroad”, was putting them "within reach of all fortunes, because of the low price of the apparatus and wires for communication and also the cheapness of the minimum installation”. As a matter of fact, another Cádiz daily had previously reported the expected arrival of "an assortment of telephones" at Bonnet's shop ${ }^{10}$, and the following February 12 the Diario de Cádiz advertised them at 25 pesetas a pair, as well as the meter of "padded copper wire for communicating" priced at one-eighth of a peseta.

It was certainly time for Bonnet to make up his mind to sell his apparatus: by then a so-called "telephone expositor” based in Seville was spending some days at Jerez de la Frontera, near Cádiz, making paid demonstrations and selling equipment of unknown origin ${ }^{11}$. In Barcelona, another pioneer of electricity, the optician Tomás José Dalmau García, had on November 19, 1877 applied for the exclusive right to introduce Bell's hand-type telephones into Spain ${ }^{12}$, and his colleague Federico Font de la Vall y Heinrich stocked Bavarian apparatus built by Friedrich Heller in his Nuremberg workshop $^{13}$. Besides, it is likely that French and British telephones were entering Spain, either units made for the concessionaries of the patents ${ }^{14}$ or pirate copies, as well as the models of Siemens und Halske or other Prussian manufacturers that were free to produce them legally once Bell had lost his patent rights in Berlin ${ }^{15}$.

\footnotetext{
${ }^{10}$ La Correspondencia. Quoted by El Guadalete, Jerez de la Frontera, January 27, 1878.

${ }^{11}$ See El Guadalete, February 2 and 3, 1878.

${ }^{12}$ Archivo Histórico de la Oficina Española de Patentes y Marcas (OEPM), file PR 5753 and contemporary registers.

13 “El teléfono", El Porvenir de la Industria, Barcelona, January 4, 1878, p. 6.

${ }^{14}$ The Maison Breguet in Paris supplied them to the French concessionaire, Cornelius Roosevelt. In Britain they were made for William H. Reynolds by the Indian Rubber, Gutta Percha and Telegraph Works, known by its location near London as The Silvertown Company.

${ }^{15}$ The oldest telephone advertisement found by the authors in the Spanish press was placed by "Keiser y Schmidt", of "Berlín, N. Johannis Strasse, 14", in El Globo, Madrid, December 9, 1877. The brief text does not indicate the maker's name, price or any other detail.
}

\section{MiCROPHONES AND MiCROTELEPHONIC STATIONS}

The work on the microphone that Edward Hughes communicated to the Royal Society on May 9, 1878 had an immediate diffusion. It seems that the issue of Enginering that appeared the following day and La Nature of June 8 were the first publications to give illustrated accounts of the new, simple invention in their respective countries. In Madrid, the fortnightly La Gaceta Industrial included the translation of the Engineering article in its issue of June 10. In an atmosphere that telephones had made very sensitive to developments embracing electricity and acoustics, some experimenters hurried to put together their own replicas of the microphone, and commercial versions also appeared. Thus, several instrument makers or retailers in London are known to have had them for sale by mid-June ${ }^{16}$. And earlier this same month as well as in July there is news of models coming from the Parisian ateliers of Adolphe Gaiffe and Eugène Ducretet ${ }^{17}$. Bonnet also built some quickly for his shop. This is known because he transferred the business, and the new owner introduced himself with an advertisement in the Diario de Cádiz of June 28, in which, among other things, he offered telephones and microphones to his customers. Both instruments appear in a catalogue of the Cádiz High-School physics laboratory published in $1889^{18}$.

Bonnet must have soon realized the possibilities offered by the association of the microphone with Bell's telephone for overcoming the chronic lack of power of the latter when used as a transmitter. He must have worked intensely on this idea, his efforts being made easier by the possibly deliberate sale of his watchmaking business, since in August 1879 at the regional exhibition held in Cádiz, among other electrical apparatus he was able to present "microtelephonic stations". According to the two concise contemporary descriptions which have been found, in addition to a microphone and a telephone the stations included a call button and a warning bell ${ }^{19}$. One of the references goes on to say that the correspondents did not have "to handle any commutator", an indication that switching from standby to talking and vice versa was probably done by simply picking up the receiver and later putting it back in its place. The oldest documented stations of this type were built in England by Louis $\mathrm{J}$. Crossley. They employed a microphone that he had registered at the patent office on February 1, $1879^{20}$, and were first described in The Telegraphic Journal of the following May 1.

\footnotetext{
${ }^{16}$ See ads of two different sellers in The Times, London, June 14, 1878, and of a third one in The Telegraphic Journal of the 15th.

${ }^{17}$ On Gaiffe's microphone see Séances de la Société Française de Physique. Année 1878, Paris, 1878, p. 101. Two models by Ducretet are described in “Le microphone”, L'Électricité, no. 8, July 20, 1878, pp. 119-120.

${ }^{18}$ José Alcolea y Tejera, Catálogo de los aparatos, máquinas e instrumentos contenidos en el Gabinete de Física del Instituto Provincial de Cádiz, Cádiz, 1889. Items nos. 1129 to 1134 are described as follows: "Bell-system Bonnet telephones, Hughes microphones modified by Bonnet and padded wire".

${ }^{19}$ Catálogo de los objetos expuestos en la Exposición Regional de Cádiz, celebrada por la Sociedad Económica Gaditana de Amigos del País, en el año de 1879, Cádiz, 1879, and José Rosetty, Guía oficial de Cádiz, su provincia y su Departamento para el año de 1880, Cádiz, 1879, pp. 144-145.

${ }^{20}$ British patent 412/1879, "Compound microphones".
} 


\section{FURTHER DEMONSTRATIONS}

After Bonnet's participation in the 1879 fair, in which he was awarded a silver medal for the ensemble of his exhibits ${ }^{21}$, no news of his telephonic activity is found until midDecember 1880. He then asked for permission to test his stations on the telegraphic lines between Seville and Cádiz (125 km) and informed his superiors that he intended to take them to the International Electrical Exhibition under preparation in Paris ${ }^{22}$. He was immediately given authorization and the trials started before the end of the year and continued at least until the following February. They happened to coincide with tests between Seville and the village of Fregenal de la Sierra, $150 \mathrm{~km}$ away in Badajoz province, which were conducted at the request of a local notable named Rodrigo Sánchez Arjona, an enthusiast of electrical communications, using his own Gower-Bell sets over the telegraph wires ${ }^{23}$. In the end, taking advantage of this fortuitous availability of equipment, Bonnet's stations were used both in Seville and Cádiz to communicate with the Gower-Bell apparatus in Fregenal ${ }^{24}$.

Besides some other electrical equipment, Bonnet, who visited the Paris Exhibition in October 1881, showed in the Spanish section his double-polarity Morse telegraph, the microtelephonic stations and a beacon for signalling hazards at sea, constructed in collaboration with his partner, a Cádiz civil engineer named Luis La Orden Otaolaurruchi. For this invention they jointly received a silver medal. Bonnet was also awarded an individual medal, apparently for the telegraph. If the correspondent of a Madrid newspaper is to be believed, the jurors also considered awarding him a bronze medal for his stations, but they finally decided not to award it on the grounds that he already had $\mathrm{two}^{25}$.

One of the main attractions of the Exhibition at the Palais de l'Industrie were the regular telephonic transmissions of performances given at the Théâtre de l'Opéra and the Comédie Française, with equipment similar to Crossley's that Clément Ader had patented in France the year before ${ }^{26}$. Back in Cádiz Bonnet applied his equipment to the same purpose,

${ }^{21}$ Acta de la sesión extraordinaria, pública y solemne, celebrada por la Sociedad Gaditana de Amigos del País, para la proclamación de los premios adjudicados en la Exposición regional, el 19 de octubre de 1879, Cádiz, 1880.

${ }^{22}$ The State Telegraphs were responsible for the organization of the Spanish participation in the fair.

${ }^{23}$ In this station, U. S. born and former Bell collaborator Frederick A. Gower combined his own version of Crossley's type of microphonic transmitter with a receiver that was a modified Bell's telephone that he had developed in France in 1878. The patents in this country (no. 137,430) and Britain (no. 2,610) were filed respectively on June 24 and 26, 1880, although the microphone was already known to the readers of The Telegraphic Journal, which had described it on the previous February 15. The Fregenal sets, which have survived, were sold by The General Telephone Agency Company of London, Gower's first licensee in England.

${ }^{24}$ See Vicente Rubio y Díaz, Elementos de física experimental, Cádiz, 1882, p. 490. The author was present at the experiments done on February 6, 1881.

25 "Congreso internacional de electricistas”, El Liberal, Madrid, October 22, 1881.

${ }^{26}$ Patent no. 135,667 of March 19, 1880, “Système de poste téléphonique et appareils employés à cet effet”. Ader's transmission arrangement was covered by patent no. 144,318, of August 9, 1881, "Système de réseau théâtral téléphonique”. so that in the summer of 1882 and for sixteen nights at his home his guests could listen to the operas sung at the Teatro Principal. The setup consisted of a series arrangement, grounded at both ends, of two microphones, one on each side of the stage, a 300-meter long single wire and eight telephones at Bonnet's house ${ }^{27}$.

\section{THE APPARATUS}

None of the telephones and microphones that Bonnet began selling in 1878 or any description of them have been found. This is not the case of his microtelephonic stations: besides the short references written on the occasion of the 1879 Exhibition, it is known what they were like in early 1882, when Bonnet filed an application for the Spanish patent that has fortunately survived ${ }^{28}$. Moreover, they were described in detail and in full agreement with the patent by his ever encouraging superior in Telégrafos José Galante Villaranda, in his book Manual de Telefonía (Madrid, 1884) ${ }^{29}$. The question of whether the 1882 stations -and the microphone and telephones they incorporated- were the earlier ones, or whether and to what extent they had been modified, still remains to be answered.

The scheme of the patented stations differs little from those of other contemporary inventors (Fig. 1). They include a microphone, two telephones, a call button, a bell and two cells, one for the bell and the other for the microphone. This particular device is in circuit with the primary of a transformer or "induction coil", the secondary of which is connected to the line. The hooks for the telephones, located on the sides of the station, drive switches that allow one to pass from the standby/call state to that of conversation. Both telephones have to be picked up in order for the microphone to operate, and in case this should fail for any reason, the right-hand telephone may be hung up and the left-hand one then used for alternately listening and talking.

Microphone and telephones are the most characteristic features of the station. The microphone (Fig. 2) consists of a series arrangement of two equal sets of three gas-carbon cylindrical rods connected in parallel. All the rods $4 \mathrm{~cm}$ long and $5 \mathrm{~mm}$ in diameter) are placed in the same direction and fit loosely at one end in the holes of a single carbon bar, while the other ends of each set of three do so in separate shorter bars. The bars in turn are screwed to a plate of "fibrous mahogany" that picks up the sonorous vibrations.

The telephone (Fig. 3) makes use of a 13-cm long, straight permanent magnet of barely square cross-section (13x12 mm). This is not solid but compound, made by pressing together six thin strips, and screwed near the end of one face and

\footnotetext{
${ }^{27}$ José Galante, “Los trabajos del señor Bonnet”, Revista de Telégrafos, September 1, 1883, pp. 357-362.

${ }^{28}$ Archivo Histórico de la OEPM, file P 2143. Bonnet's application bears the date of January 21.

${ }^{29}$ The only difference worth mentioning is that in the application for the patent the current sent by one station to call the other passes through the bell of the latter and makes it ring, while in Galante's description the current activates a relay that in turn connects the bell to the local cell, an arrangement that must have allowed the station to operate over longer distances.
} 
perpendicularly to it, carries a small soft iron cylinder that forms the nucleus around which the coil is wound. A very thin diaphragm of the same material, with a hole $5 \mathrm{~mm}$ in diameter cut at its centre, is placed very close to the nucleus -the distance can be finely adjusted from the back of the telephone- and normal to its axis. All these parts are lodged in a cylindrical wooden box that is closed by a funnel-shaped piece to keep the diaphragm in place, and is provided with a handle enveloping the magnet. The user can therefore hold this handle comfortably parallel to his face and not at a right angle to it as in many telephones of the time.

Thus, Bonnet increased the sensitivity of Bell's telephone by thinning the diaphragm and placing it as close as possible to the coil nucleus, instead of resorting to employing powerful magnets, a more habitual procedure in those days. Besides, taking inspiration from some musical instruments, with the hole in the diaphragm he sought to reinforce its vibration with the cooperation of the wooden box behind ${ }^{30}$. According to Galante in his book, this design, besides allowing substantial economies, had proved its technical qualities when the telephone worked perfectly as a transmitter between Seville and Cádiz over the telegraphic lines.

\section{DIFFUSION}

From the start, the telephone in Spain was de facto included in the State's monopoly of the telegraph and was not the object of any known specific governmental action until 1882. A decree then explicitly recognized the freedom to establish private telephone lines linking premises belonging to the same owner, and the procedure to grant the corresponding authorization was published subsequently. These texts also contained provisions regulating State concessions of urban public telephone service, and tenders were invited for the cities of Madrid, Barcelona and Bilbao which were finally revoked. After a long impasse, in 1884 it was decided that the urban networks were to be set up and exploited by the State through its telegraphic organization, and permissions for private lines were restricted to cases where the State could not provide them. Telégrafos only had operational networks in Madrid, Barcelona and Valencia when in 1886 the Government changed its mind again and returned to the system of concessions, which was to be in effect for a long time, allowing public service to spread progressively to many other places [2].

Therefore, from 1878 and during the following six years the end-users of telephonic equipment were exclusively individuals, companies or other entities who needed it to carry on their activities, and not public service operators. A comprehensive study of this long initial stage of the telephone in Spain has not yet been done, but the local data coming to light suggest the existence, especially in the more industrialized parts of the country, of a great number of lines, put up more often than not without Government permission.

\footnotetext{
${ }^{30}$ The hole also allowed the end of the nucleus to be seen while adjusting its distance to the diaphragm.
}

Thanks to an 1883 article by Galante ${ }^{31}$ it is known that Bonnet's stations were in use not only in Cádiz and its vicinity (San Fernando, Puerto de Santa María, Jerez, Faros de Chipiona, Trafalgar and Conil), but also in Barcelona, Seville, Málaga, Córdoba, Cartagena and Havana (Cuba). Galante specifies that in Cartagena, besides several individual lines, there was a small private network with seven stations and a central exchange also made by Bonnet. This was probably of the type described in his book (Fig. 4), where he adds that there were others in Córdoba and Valencia. According to Márquez, "several hundred" stations had been placed in Spain, "despite the tendency that exists in our country to have this kind of apparatus supplied from abroad" 32 .

One of the bidders for the tenders that took place in October 1882 to assign the telephone networks of Madrid and Barcelona was the already mentioned Tomas José Dalmau, who acted on behalf of the Sociedad Española de Electricidad, the first electrical company in the country, the establishment of which he had promoted the previous year in Barcelona. According to a published statement relative to Madrid ${ }^{33}$, without renouncing the use of other equipment, the company intended to give preference to Bonnet's station, "in perfect agreement with its enlightened inventor, who is going to give his apparatus the beauty and external attractiveness corresponding to its real value as a scientific organism [sic]”. As already mentioned, given that the tenders had no practical outcome, the embellishment intended by Dalmau may never have been achieved. In any case, there was an immediate opportunity for Bonnet's equipment in the small official telephone network planned to link a number of State institutions in Madrid, but Telégrafos, which was in charge of its establishment, decided as usual to ignore all autochthonous inventions, including those of its own employees, and according to Galante's testimony in his book the network began to operate in 1883 with Ader and Breguet equipment ${ }^{34}$.

In 1888, after the concession was awarded to a Cádiz cloth merchant named Joaquín Lahera Juillet in a public invitation for tenders held on January 10, Bonnet set up the city's first telephone network. It began to operate early in June with twenty-six subscribers, a number that had increased to a hundred by the end of the year ${ }^{35}$. No information has been found about the installation excepting Marquez's reference to a "professional periodical" that had allegedly described it as "a model network" ${ }^{36}$. So nothing is known about whether or not Bonnet used his own equipment. Be that as it may, in

\footnotetext{
${ }^{31}$ José Galante, “Los trabajos del señor Bonnet (continuación)”, Revista de Telégrafos, October 1, 1883, pp. 372-374.

${ }^{32}$ Op. cit. (2).

${ }^{33}$ Memoria descriptiva de una red telefónica con destino al servicio público..., Madrid, 1883.

${ }^{34} \mathrm{He}$ also compared the prices in Spain of some of Bonnet's apparatus with those of other foreign manufacturers. Bonnet's station cost between 100 and 120 pesetas, “depending on the wood, sockets and flexible wire used", Fein's ("with its magneto-electric apparatus") cost 300, Ader's 250 and De LochtLabye's 150. Bonnet's telephones were still sold at 25 pesetas a pair, and those of Ader and D'Arsonval at 100 and 80, respectively.

${ }^{35}$ See El Guadalete, June 5, 1888 and Revista de Telégrafos, April 1, 1889, p. 108.

${ }^{36}$ Op. cit. (2).
} 
1902, after Lahera's death, Bonnet started operating the network in his own name. Having retired from Telégrafos in 1892, he no longer had any legal impediment to do so.

\section{CONCLUSION}

Enrique Bonnet's name deserves to figure on the list of European telephone pioneers, no matter the scarcity of details about his earliest work or the limited diffusion of his apparatus at a time when any kind of protection for innovators was something unusual in Spain.

\section{ACKNOWLEDGEMENTS}

The authors wish to thank the Diario de Cádiz for granting them access to their historical collection and the Fons Històric de Ciència i Tecnologia, Universitat Politècnica de Catalunya, and the OEPM for providing them with a digital copy of Galante's very rare book and Bonnet's patents, respectively.

\section{REFERENCES}

[1] J. Sánchez Miñana, El telegrafista murciano Enrique Bonnet, Colegio Oficial de Ingenieros de Telecomunicación de la Región de Murcia, Murcia, 2007.

[2] S. Olivé and J. Sánchez Miñana, "De las torres ópticas al teléfono: el desarrollo de las telecomunicaciones y el Cuerpo de Telégrafos”, in M. Silva (ed.), El Ochocientos. Profesiones $e$ instituciones civiles, Técnica e ingeniería en España, vol. V, Real Academia de Ingeniería, Zaragoza, 2007.

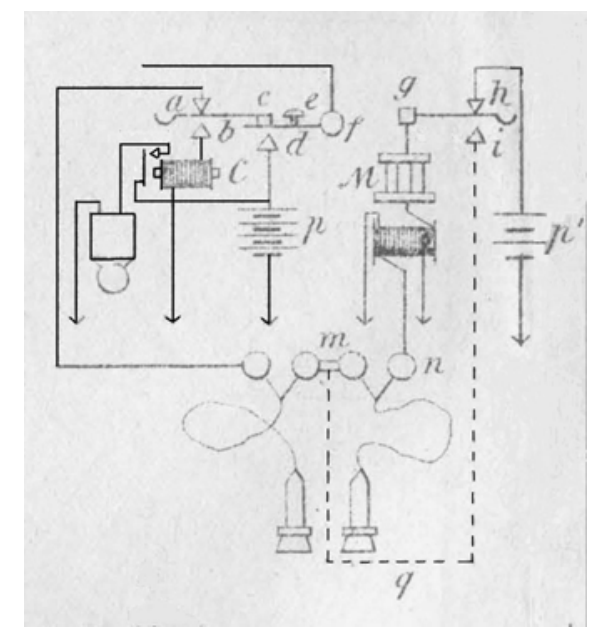

Fig. 1. Diagram of Bonnet's microtelephonic station (From Galante's book). The induction coil appears below the microphone $M$. Both telephones are shown in use so that the hooks provide continuity at $a$ and $h . C$ is a relay that makes the bell ring when the correspondent station calls by pressing button $e$. Only one wire is used for the line (top). The arrows indicate earth connections.

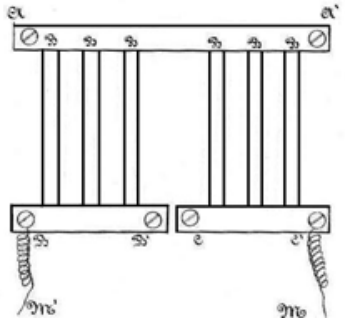

Fig 2. Bonnet's microphone (From his application for Spanish patent 2143).

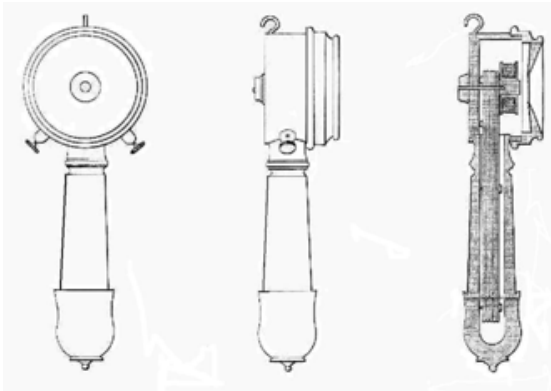

Fig 3. Bonnet's telephone (From his application for Spanish patent 2143).

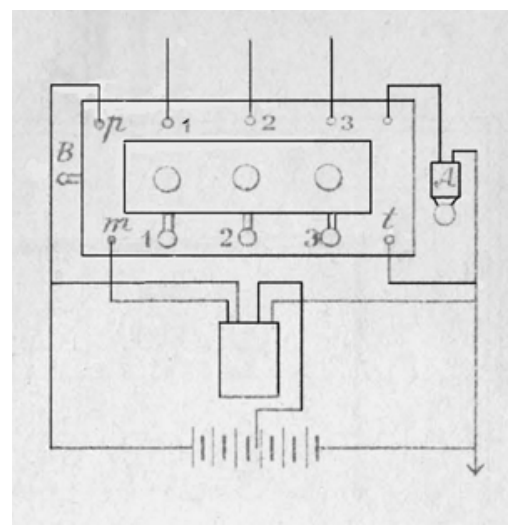

Fig. 4. Bonnet's telephone exchange (From Galante's book). It shows the general setup of a "central commutator" for three subscribers. The five top terminals are connected thus: one $(p)$ to the local cell, three to the respective line wires $(1,2,3)$ and one to the bell $A$, while the two bottom ones go one $(\mathrm{m})$ to the line input of the operator's microtelephonic station and the other $(t)$ to earth. The sketch of the exchange itself includes, besides the seven terminals, what looks like an indicator board with three circular disks, and, sticking out from below, the extremities of an equal number of levers that end up "in an ivory button on which the number corresponding to the indicator and the wire it belongs to is engraved". Another side button $B$ also appears. With the levers in the standby, vertical position, if a subscriber, say 1 , calls, sending his battery current, "the disk of the same number will show up" and the bell will ring until $B$ is pressed. The operator will then displace lever 1 to the left, thereby communicating with the caller. If he or she wants to talk, say with 3 , the operator will displace both levers 1 and 3 to the right. "The subscribers announce the end of the conversation by sending their currents". 